\title{
THE IMPORTANCE OF MATHEMATICAL MODELING IN DIGITAL CUSTOMS POLICY
}

\author{
Bayotbek Jumabaevich Otaniyozov
}

Associate Professor, Faculty Of Customs, Institute Of The State Customs Committee, Uzbekistan

\section{ABSTRACT}

The article discusses the concept of digital economy, definitions of digital economy, customs policy, mathematical modeling in digitalization of the customs sector and its importance.

KEYWORDS:- Digitization, digital technology, digital economy, electronic customs, digital customs, customs policy, mathematical modeling, trade security.

\section{INTRODUCTION}

The importance of digital customs policy today is that as the economy develops in a society, the process of collecting, processing, making decisions, searching for and transmitting economic information in the process of increasing the volume and quantity of economic information requires very large systematic calculations and time. Modern computer technologies are used to perform such work and calculations without errors and quality. In these processes, people use computer techniques and technology as a tool in the development of the economy. The main task of these tools is to execute the sequence of commands (algorithm) loaded on it without errors and quickly. Since digital customs is part of the "digital economy," we will first focus on the concept of the digital economy.

The digital economy is not any other economy that needs to be created from scratch, but it is about transforming an existing economy into a new system by creating new projects, technologies, platforms and business models based on digitalization and introducing them into everyday life.

In 1995, American programmer Nicholas Negroponte coined the term "digital economy." Today, the term is used by politicians, economists, journalists and entrepreneurs all over the world. In 2016, the World Bank published the first report on "Digital Dividends" on the state of the digital economy in the world.

When we talk about the process of "digitization" of society, especially the economy (in English digitization, ie digitization, sometimes means digitalization), we must first clarify the term. In 
CURRENT RESEARCH JOURNAL OF PEDAGOGICS 2(11): 161-167,

November 2021 DOI: https://doi.org/10.37547/pedagogics-crjp-02-11-31

ISSN 2767-3278

(C)2021 Master Journals

Crossref do: 81 Google

Accepted 25th November, 2021 \& Published 30 ${ }^{\text {th }}$ November, 2021

the broadest sense, the process of "digitization" usually refers to the socio-economic change that begins with the widespread use and assimilation of digital technologies. In short, the creation, processing, exchange and transmission of information bases in society, especially in the economy, are the main components of digitization.

There are different definitions of the concept of digital economy. For example, R. Meshcheryakov, a Russian scientist and professor at Tomsk State University, believes that there are two approaches to the term "digital economy."

The first approach is the so-called "classic" digital economy, which describes the exclusive domain of electronic goods and services in an economy based on digital technologies. These include classic examples - telemedicine, distance learning, drug sales (movies, TVs, books, etc.) and more.

The second approach is "digital economy" economic production using advanced digital technologies.

The Russian scientist ML Kaluzhsky described the digital economy as "economic Internet activity, as well as forms, methods, means and communication environment for its implementation" [5].

What does the development of the digital economy give us?

The digital economy significantly increases the living standards of people in society, which is its main indicator.

The digital economy is a major ally of corruption and the black economy. Because numbers seal everything, store it in memory, provide information quickly when needed. In such circumstances, it is impossible to hide, change any information or make secret transactions, not to give full information about this or that activity, the computer will show it all. The abundance and structure of the data prevents deception and deception, because it is impossible to deceive a digital system embedded in memory. As a result, the economy will not be able to steal, spend inefficiently and aimlessly, exaggerate or hide. This will increase the flow of legal funds into the economy, taxes will be paid on time and correctly, budget allocations will be transparent, funds allocated to the social sphere will not be stolen, schools, hospitals, roads will be fully accessible, social spheres will be improved and so on.

The choice of the path of development of the digital economy in society opens new directions in the field of information technology and electronic document management in general. Also, the development of "digital technologies" contributes to the provision of quality communication over the world wide web.

Who will develop the digital economy?

The National Agency for Project Management under the President of the Republic of Uzbekistan is the competent authority in the field of widespread introduction and development of the digital economy. In addition, the Ministries of Economy, Finance, Information Technology, Justice, Committees and a number of other government agencies have specific responsibilities and tasks for the development of the digital economy.

In our opinion, if we consider the processes associated with the production, consumption, distribution, delivery of goods as an economic problem, the search for and identification of solutions to such problems using computer communication technologies based on mathematical modeling is the basis for calling the economy a digital economy.

Often in a digital economy, data collection, processing, and sharing are not considered to be a difficult problem. However, the importance of 
CURRENT RESEARCH JOURNAL OF PEDAGOGICS 2(11): 161-167,

November 2021 DOI: https://doi.org/10.37547/pedagogics-crjp-02-11-31

ISSN 2767-3278

(C)2021 Master Journals

Crossref dof 81 Google

Accepted 25 $5^{\text {th }}$ November, 2021 \& Published 30 ${ }^{\text {th }}$ November, 2021

mathematical modeling in solving, analyzing, and putting into practice economic problems that require real numerical solutions is great.

It is obvious that the first task in the policy of the "digital economy" will be to build a mathematical model of the economic problem on the basis of mathematical modeling. Mathematical modeling of an economic problem is the process of translating it into mathematical language in an objective state. A mathematical model of an economic problem is its expression in mathematical language, that is, its expression using numbers, tables, graphs, formulas, equations, inequalities, and other mathematical symbols [6].

It is known that we can look for a solution to a mathematical problem generated on the basis of mathematical modeling in several different ways. However, the most optimal of such methods is selected and an algorithm for solving the problem is created using this method. This algorithm is then downloaded to a computer using one of the modern programming languages. Any information uploaded to the computer is recorded in the binary number system (using the numbers "0" and "1"). Based on this, the computer performs all the tasks assigned to it using a binary number system.
In this regard, such a method of solving problems or solving problems in the economy today is called digitization of the economy.

The first step in a digital economy is to study the problem or problem in detail and build a mathematical model of it, as well as an algorithm to determine the solution. The second step is to express the problem or problem solving algorithm in the programming language and perform the required actions using a computer. The third step is to analyze the identified solution and make decisions about the initial economic issue or problem (Figure 1).

From this we can conclude that the stage of mathematical modeling of an economic issue or problem is important in digital customs policy. This is because if the mathematical model of the economic problem does not fully correspond to the content of the original economic problem, the opportunity to find the optimal solution is lost. Therefore, the process of mathematical modeling is an important step in digital customs policy.

Mathematical modeling of economic processes in digital customs policy requires from each employee not only a system of mathematical knowledge, but also knowledge such as logic, identification, analysis of the most important data, the correct use of computer technology. 
CURRENT RESEARCH JOURNAL OF PEDAGOGICS 2(11): 161-167,

November 2021 DOI: https://doi.org/10.37547/pedagogics-crjp-02-11-31

ISSN 2767-3278

(C)2021 Master Journals

Crossref doi Google

Accepted 25th November, 2021 \& Published $30^{\text {th }}$ November, 2021

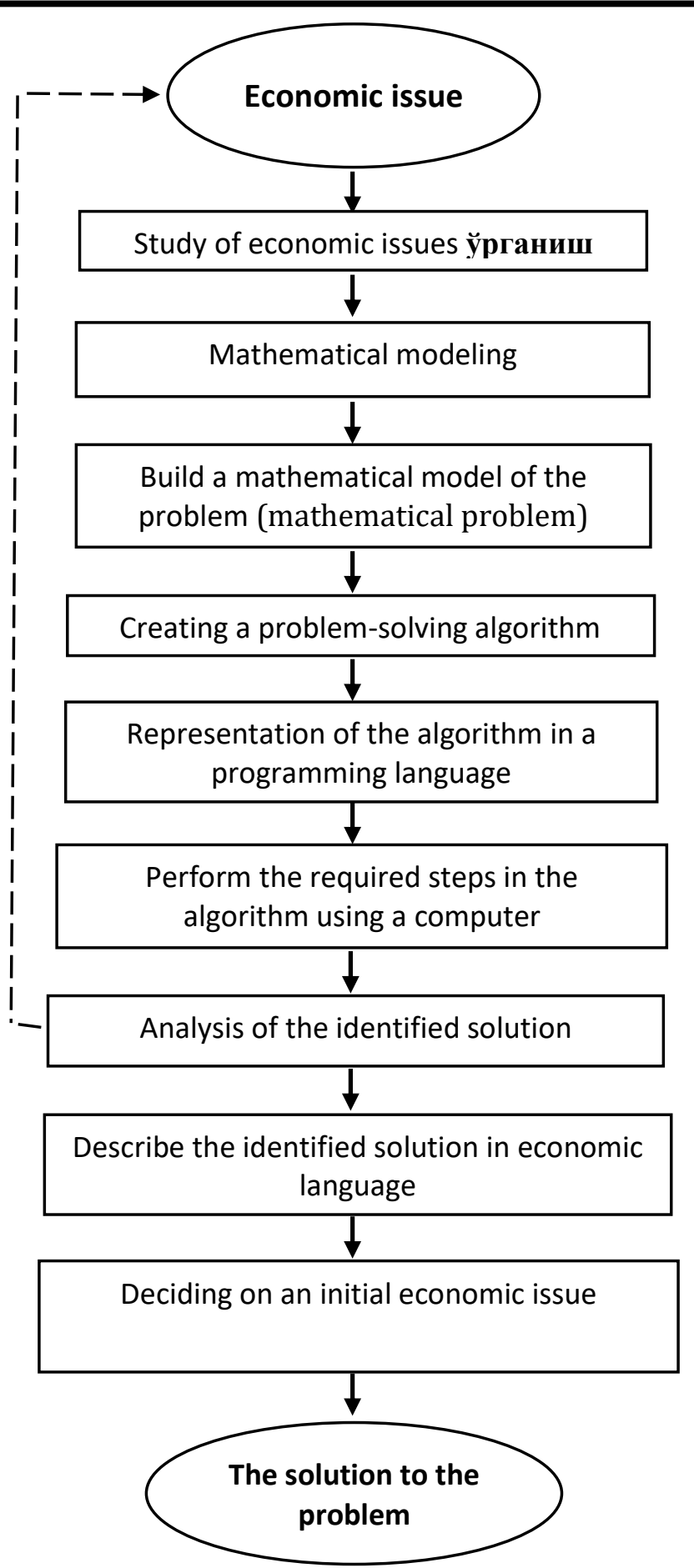

FIGURE 1. THE HIERARCHY OF THE DIGITAL ECONOMY. 
CURRENT RESEARCH JOURNAL OF PEDAGOGICS 2(11): 161-167,

November 2021 DOI: https://doi.org/10.37547/pedagogics-crjp-02-11-31

ISSN 2767-3278

(C)2021 Master Journals

Crossref do: 81 Google

Accepted 25 $5^{\text {th }}$ November, 2021 \& Published 30th November, 2021

Today, the country is carrying out consistent reforms aimed at increasing the efficiency of the state customs service using modern information and communication technologies.

Simplification of customs procedures, an integral part of the Decree of the President of the Republic of Uzbekistan dated June 5, 2020 "On reforming the customs administration and improving the activities of the state customs service of the Republic of Uzbekistan" PF-6005, achieving efficiency through the widespread introduction of advanced digital technologies On September 10, 2021, the Decree of the President of the Republic of Uzbekistan No. PF-6310 "On simplification of customs procedures and further improvement of the organizational structure of the state customs service" was adopted.

Among the main tasks set by this decree, great attention was paid to the widespread introduction of information and communication technologies in the customs authorities and the process of digitization of the industry. In particular, the establishment of "Remote Electronic Declaration" customs posts within the total number of states of the State Customs Committee from October 1, 2021, and from December 1, 2021 at the border customs posts for goods of veterinary and phytosanitary bodies The customs information system "Single Window" is responsible for the verification and registration of documents [2].

The main goal is to reform the customs administration and improve the activities of the State Customs Service of the Republic of Uzbekistan, to form a "digital customs", which is a logical continuation and development of "paperless and electronic customs", to accelerate the implementation of international norms and standards in customs.

In a sense, this Decree includes tasks aimed at reforming the customs administration, increasing the efficiency of the customs authorities and the further development of the "digital customs" system.

Therefore, in order to timely fulfill the tasks set by the Decree, consistent reforms are being carried out in the customs sphere to increase the efficiency of the state customs service of the Republic of Uzbekistan with the widespread use of modern information and communication technologies.

Reforms in the field of incorporating the standards and recommendations of the World Bank, the World Trade Organization, the World Customs Organization and other international organizations into national legislation require the improvement of customs administration and simplification of customs procedures. The implementation of such work, in turn, requires the development of "paperless and electronic customs", ie "digital customs".

We know that the "digital customs" policy was introduced in the world a few years ago. For example, in order to demonstrate the active use of information and communication technologies in the customs authorities in order to collect and ensure payment of customs duties, control the movement of goods, people, vehicles and funds, as well as to ensure the security of cross-border trade, the World Customs Organization in 2016 Digital Customs) was declared the year [4].

From the above, it is clear that the study of issues or problems in the "digital customs" policy, the widespread use of mathematical apparatus in the field of solving or solving them and making important decisions, the implementation of important reforms based on mathematical modeling is one of the main tasks. Therefore, there is a need to develop new approaches to the development of digital customs in the country on the basis of the widespread introduction of 
CURRENT RESEARCH JOURNAL OF PEDAGOGICS 2(11): 161-167,

November 2021 DOI: https://doi.org/10.37547/pedagogics-crjp-02-11-31

ISSN 2767-3278

(C)2021 Master Journals

Crossref dof 81 Google

Accepted 25th November, 2021 \& Published 30 ${ }^{\text {th }}$ November, 2021

mathematical modeling methods. We can

illustrate this using the following diagram

(Figure 2).

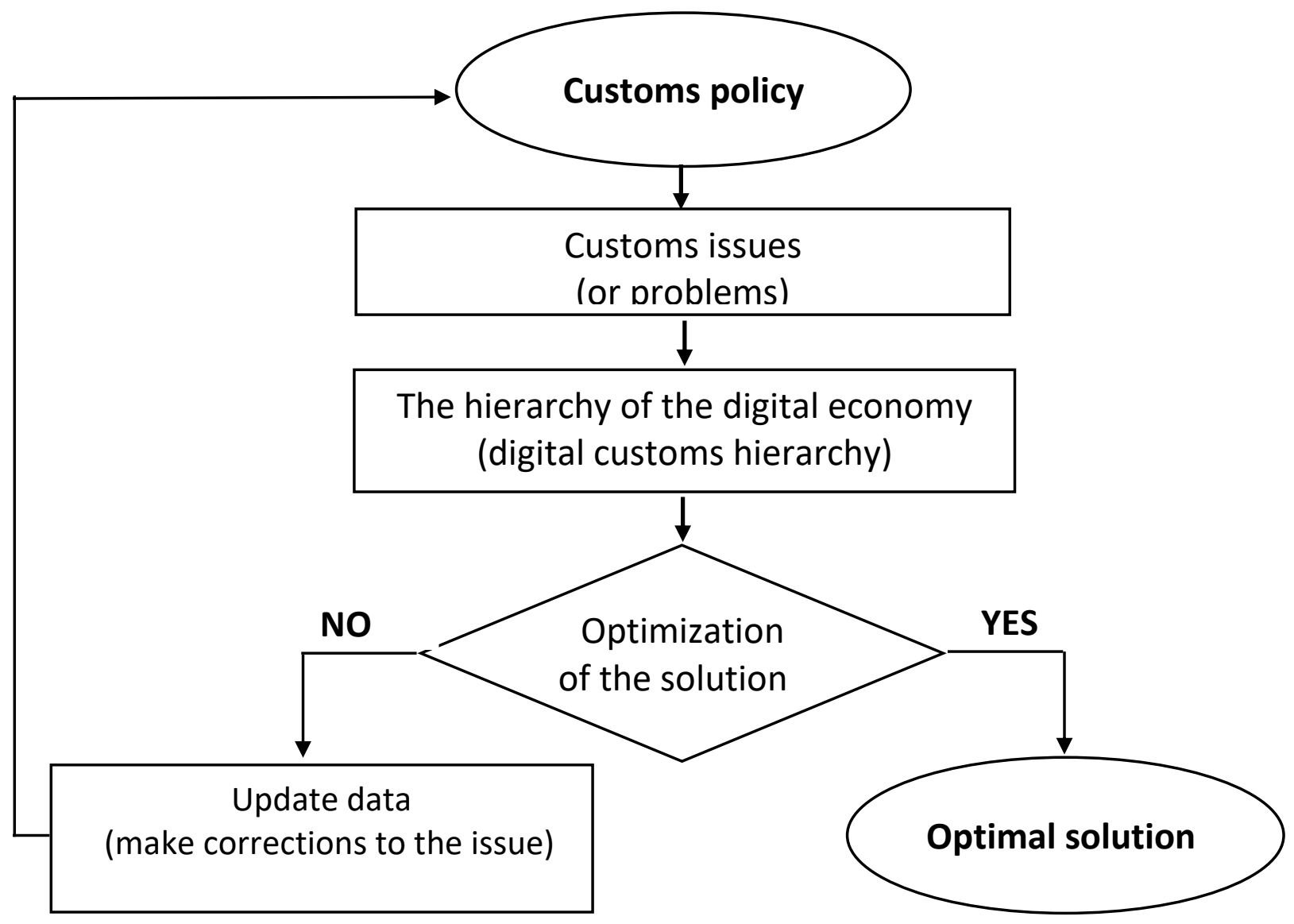

FIGURE 2. ALGORITHM FOR DIGITIZATION OF THE CUSTOMS SYSTEM.

Hence, the digitization of the customs system is a method of economic mathematical modeling based on mathematical knowledge of the collection, processing, mutual exchange of information relevant to the field, the search for a numerical solution to an existing problem or issue.

\section{Conclusion}

In conclusion, we can say that the development of the "digital customs" system in the customs authorities of the Republic of Uzbekistan gives the following positive results:

- customs procedures will be updated and integrated into recognized international norms and standards;

- bureaucratic barriers to the activities of customs authorities will be eliminated; 
CURRENT RESEARCH JOURNAL OF PEDAGOGICS 2(11): 161-167,

November 2021 DOI: https://doi.org/10.37547/pedagogics-crjp-02-11-31

ISSN 2767-3278

(C)2021 Master Journals

Crossref do: 81 Google

Accepted 25 $5^{\text {th }}$ November, 2021 \& Published 30 ${ }^{\text {th }}$ November, 2021

- simplification and simplification of customs cargo declaration;

- The period of customs clearance for the export and import of goods will be reduced several times and the level of customs clearance will increase;

- The exchange of information in the field will be accelerated, time will be used efficiently and excessive paperwork will be prevented;

- Many processes in the customs system will be automated with the help of information and communication technologies;

- Ensuring the economic security of the state will be further improved;

- effective interdepartmental cooperation, etc.
Всемирной таможенной организации. URL:http://www.wcoomd.org.

5. Калужский М.Л. Маркетинговые сети в электронной коммерции: институциональный подход . - М.; Берлин: Директ-Медиа, 2014. - 402 с.

6. Отаниёзов Б.Ж. Божхона тизимидаги айрим иқтисодий масалаларни математик моделлаштириш, Тошкент ахборот технологиялари университети., ТАТУ хабарлари журнали.1-сон, 2008й.

\section{REFERENCES}

1. Decree of the President of the Republic of Uzbekistan dated June 5, 2020 No PF-6005 "On reforming the customs administration and improving the activities of the state customs service of the Republic of Uzbekistan."

2. Decree of the President of the Republic of Uzbekistan dated September 10, 2021 No. PF-6310 "On simplification of customs procedures and further improvement of the organizational structure of the state customs service."

3. State program for the implementation of the Action Strategy on the five priority areas of development of the Republic of Uzbekistan for 2017-2021 in the "Year of Science, Enlightenment and Digital Economy".

4. Implications of Big Data for Customs. How It Can Support Risk Management Capabilities. Официальный сайт 